\title{
Biology Education a Panacea for Sustainable National Development
}

\author{
Sallau Ibrahim Ahmad", Bilkisu Bello Abubakar ${ }^{1, ~ *, ~ S a n i ~ Y a u ~}$ \\ ${ }^{1}$ Department of Biology, School of Science Education, Sa'adatu Rimi College of Education, Kumbotso, Nigeria \\ ${ }^{2}$ Child Development Centre, Sa'adatu Rimi College of Education, Kumbotso, Nigeria
}

Email address:

twinsmum@gmail.com(B.B. Abubakar)

${ }^{*}$ Corresponding author

To cite this article:

Sallau Ibrahim Ahmad, Bilkisu Bello Abubakar, Sani Yau. Biology Education a Panacea for Sustainable National Development. Frontiers in Environmental Microbiology. Vol. 4, No. 2, 2018, pp. 71-74. doi: 10.11648/j.fem.20180402.14

Received: December 29, 2017; Accepted: February 11, 2018; Published: April 14, 2018

\begin{abstract}
Biology is one of the pre-requisite subject for many field of learning including botany, anatomy and physiology, microbiology, medicine, agriculture, pharmacy, biotechnology, and others. Biology and biology education contributes immensely to the technological growth and development of any nation. This paper discussed the meaning and concept of biology and biology education, factors militating against the development of biology education in Nigeria, and the role of biology for sustainable development. The paper recommended that, government at all levels should provide adequate instructional materials and laboratory equipments for effective teaching and learning, qualified teachers should be employed for teaching the subject both in secondary and tertiary schools.
\end{abstract}

Keywords: Biology, Education, Equipments, Instructional Materials, Laboratory, Sustainable Development

\section{Introduction}

The progress in science and technology during the last few decades has conclusively changed our conception of the significance of various scientific disciplines [1]. The increasing chemicalization of the knowledge is related to the fact that, the progress of learning does not only widens the scope of our knowledge but deepens it and make it more exact [1]. Science education is the field concerned with sharing scientific knowledge, and methods with people not considered part of scientific community. Science education has been identified as one of the major bedrock for the sustainable development of our country, which is seen as knowledge or ideas acquisition relevant to science [2], and is concerned with important of knowledge on environment, as well as others. Baba [3] opined that no nation can develop without science education. Science is therefore receiving much emphasis in education because of its significance and relevance to life and society [4]. Biology as a branch of science and the pre-requisite subject for many field of learning contributes immensely to technological growth of the nation. The study of biology both in tertiary and senior secondary schools can equip the learners with useful concepts, principles and theories that will enable them face challenges before and after graduation. The importance of biology and biology education for sustainable national development cannot be overemphasized as it finds its way into agriculture, pharmacy, ethnobotany, medicine, biotechnology, and other related fields. This paper intended to discuss the meaning and concept of biology, factors affecting the development of biology education as well as the role of biology education for sustainable development.

\section{Concept and Meaning of Biology Education}

The term biology is coined from two Greek words "bios" meaning life and "logos" meaning to study, and this simply defined as the study of life or the study of plants and animals [5]. According to oxford [6] biology is the study of living organisms, and these includes structure (gross and morphological), functioning, origin and evolution, classification, interrelationship and distribution. Biology as pointed by Nakano [7] is the science that deals with the study 
of living things, since it is the study of living things there are certain recognizable characteristics by which living things which includes; movement, death, respiration, growth, excretion, irritability, reproduction, and nutrition. Chukunyerenmuwa [8] asserted that, biology remains one of the basic sciences whose teaching and learning is universally known to be efficient and successful, if only undertaken simultaneously with the help of adequate instructional resources and facilities. Biology plays a vital role in the field of biochemistry, genetics, physiology and anatomy, ecology, medicine Olutola et al., [9] and molecular biology and as such biology has been made a central focus in some human activities including being a solution to the problem of food scarcity, health, hygiene, family life, poverty eradication, management and conservation of natural resources, biotechnology, ethics, various social vices and as well lack of appropriate infrastructural materials. Aina [10] stated that, biology education is important to any growing economy like Nigeria. Many graduate of biology education are self employed and employers of labour; many owned schools for themselves where people works and earn their living while some are into fish business.

\section{Problems Militating Against Biology Education Development in Nigeria}

\subsection{Improper Curriculum Development}

Biology education has not been given an appropriate in the Nigerian school curriculum [11]. Obiaga (1997) in [11] opined that, the bulk of what is taught in schools is imported from other developed countries.

\subsection{Inadequate Laboratory Equipments and Instructional Materials}

Onasanya and Omosewo [12] reported that, there were inadequate resources for the teaching of biology subject in Nigerian secondary schools. According to Chukunyerenmuwa [8] the cost of effectively teaching biology is so high that Nigeria may not be able to afford at least in this period of economic recession, an adequately equipped laboratories and provision of adequate instructional materials for the teaching of biology. Many practical classes are not carried out due to the absence or inadequate laboratory equipments, reagents, as well as apparatus.

\subsection{Lack of Qualified Teachers}

Teachers quality has a strong bearing on societal survival since the quality of education in any society depends on the quality of its teachers as asserted by Ibrahim [13]. Aina [10] observed that, shortages of science (biology) teachers is what dominated Nigerian schools. He further stated that, recruitment of biology teachers is no longer based on merits; those who are qualified for biology teaching are not given employment because they don't have godfather in the government and this lead biology teaching appointment to favouritism and nepotism.

\subsection{Methods of Teaching}

One of the major biology education is to teach students some investigative skills such as observing, measuring, classifying, recording, analyzing, interfering, experimenting as well as others [14]. Due to the fact that majority of the schools lack qualified biology teachers, most of the teachers does not imply appropriate methods of teaching as well as strategies of imparting knowledge to learners memories.

\subsection{Corruption}

Corruption is the greatest challenge to development of biology education in Nigeria which leads to many problems the country facing currently Aina [10]. Its the corruption that makes schools administrator mismanaged fund meant for purchasing laboratory equipments and asked the teachers to make sure students still pass in examinations by all means [10].

\subsection{Poor Funding}

Another key challenge militating against the growth of biology education in Nigeria is poor funding. Nigerian government does not provide adequate fund for the provision of conducive and enabling the environment to facilitate the effective teaching and learning process as well as research [13]. Research in biology education requires a huge investment and capital.

\section{Biology Education and Sustainable Development}

Sustainable development can be conceived within the concept of growth, advancement, conservation and preservation of the gains of development for the benefit of the present and future [1]. Olorode [15] considered sustainable development as development that meets the needs and aspiration of the present without compromising the ability of future generations to meet their own needs. Nnabuo and Asodike [16]; Olorode [15] stated that, sustainable development is an approach that combines the developmental needs and aspiration of the present without compromising the ability of the future while also maintaining ecological integrity. Three aspects of sustainable development has been in recognition i.e economic, social and environmental. In this paper the role of biology education in attaining the sustainable development will be discuss under the aforementioned aspects.

\subsection{Bio-Fermentation}

Is a process whereby food and organic products are produced through fermentation in a bioreactor by organisms including yeast, fungi and algae. This process involves the selection of a suitable microbial culture that has the metabolic potential to produce the desired products. The 
medium in which the culture is fermented is carefully chosen. Production by bio fermentation has been deemed advantageous as fermentation utilizes renewable feedstocks instead of petrochemicals in which some of the renewable feedstocks are agricultural waste [17].

\subsection{Biofuels}

The rise in biofuels production is as a result of increasing demand of fuels globally. It is a gaseous, liquid or solid fuel that contains an energy content derived from a biological sources. The organic matter that makes up living organisms provides a potential source of trapped energy that is beginning to be exploited to supply the ever-increasing energy demand around the world. Examples are rapeseed methyl ester, biogas, gasohol and others [6]. Yahaya [17] explained that, Nigeria as a developing country may be considered a top destination for biofuel production in terms of cost effectiveness production.

\subsection{Bioinformatics}

Is the collection, storage and analysis of DNA and proteinsequence data using computerized systems. In this situation much of the data generated by genome sequencing projects and protein studies is held in various databanks and made available to researchers throughout the world via the internet. There are many computer programs developed to analyze sequence data which enable the user to identify similarities between newly sequenced materials and existing sequences. This allows predictions the structure and function of a protein from its amino acid sequence data or from the nucleotide sequence of its gene [6].

\subsection{Bioremediation}

Environmental contamination due to rapid increase in population, industrialization and urbanization is one of the most popular challenges nowadays. Bioremediation is a technology that focuses on removing the contaminants from the environment. Sharma [18] sees bioremediation as a process whereby contaminants or organic wastes are biologically degraded under controlled conditions to an innocuous state, or to levels below concentration limits established by regulatory authorities. Bioremediation techniques are typically more economical than traditional methods such as incineration and others. Some of the microorganisms use in this techniques includes; Nitrosomonas, Mycoccus, Xanthofacter, Norcardia, Pennicillium, actinobacter, Rhizoctomia, Mycobacterium as well as others Singh et al., [19]. The process of bioremediation involves biotransformation and biodegradation by converting the contaminants to non-hazardous or to less hazardous substances Singh et al. [19]. This techniques is less cost, effective and efficient as well as environmentally friendly.

\section{Conclusion}

The importance of biology and biology education for sustainable national development cannot be overemphasized as it finds its way into agriculture, pharmacy, ethnobotany, medicine, biotechnology, and other related fields. Many factors are responsible for the failure of effective teaching and learning the subject in Nigerian secondary and tertiary schools, and can be reduced to a maximum point of consideration.

\section{Recommendations}

This paper recommends the following:

a. Curriculum innovators should emphasize on providing a proper curriculum for biology education.

b. Government at all levels, should provide adequate instructional materials and laboratory equipments, and other facilities.

c. Government should only recruit competent and qualified teachers who can teach biology effectively.

d. Biology teachers should try as much as possible to improve their methods of teaching through innovation.

e. Excursion, demonstration and practical methods of teaching should be given much emphasis.

f. Learners should be motivated and be made to draw their attention into learning the subjects.

\section{References}

[1] G. I. Baba (2014). The role of Chemistry Education in small scale Industries for Achieving Sustainable National Development. Kano Journal of science education, 9 (1): 97-103.

[2] E. B. Nnamdi (2014). The role of Chemistry Education in National Development. The International Journal of Engineering and Science, 3(3): 12-17.

[3] G. I. Baba (2017). The role and challenges of chemistry education in small and medium scale industries for science and technology education for the development of sustainable society in Nigeria. Being a paper presented at 2nd National science education conference held at Saadatu Rimi College of Education, Kumbotso, Kano, on 31st October-3rd November.

[4] C. Nwagbo and U. C. Uzoamaka (2011). Effects of biology practical activities on student's process skill acquisition. Journal of Science Teachers Association of Nigeria.

[5] M. C. Michael (2015). Essential Biology for Senior Secondary Schools. Tonad Publishers Ltd., Ogun, pp 2.

[6] Oxford Science Dictionary (2005). 5th ed., Oxford University Press Inc. New York, pp 65.

[7] M. R. Nakano (2017). Factors Militating Against Female Students Performance in Biology. Being a paper presented at 2nd National science education conference held at Saadatu Rimi College of Education, Kumbotso, Kano, on 31st October-3rd November.

[8] A. M. Chukunyerenmuwa (2013). Effect of Students Improvised Instructional materials on Senior Secondary School Student's Achievement in biology. Unpublished M.ED submitted to department of science education, University of Nigeria Nsukka. 
[9] A. T. Olutola, D. S. Daramola and E. O. Bamidele (2016). Comparative Effects of Practical and Alternative to Practical Methods on Students' Academic Performance in Biology. International Journal of Educational Benchmark, 3 (1): 67-80.

[10] J. K. Aina (2013). Importance of Science Education to National Development and Problems Militating Against it's Development. American Journal of Educational Research, 1 (7): 225-229.

[11] C. I. Okenyi (2013). The challenges and prospects of biology education in Nigeria. Journal of Assertiveness, pp 1-9.

[12] S. A. Onasanya and E. O. Omosewo (2011). Effect of Improvised and Standard Instructional Materials on Secondary School Student's Academic Performance in Physics in Ilorin, Nigeria. Singapore Journal of Scientific Research, 1 (1): 6876.

[13] H. E. Ibrahim (2013). The Problems and Prospects of Agricultural Education in Nigeria. Journal of Resourcefulness and Distinction, 7 (1): 1-9.

[14] E. Omorogbe and J. C. Ewansiha (2013). The Challenges of Effective Science Teaching in Nigerian Secondary Schools.
Academic Journals of Interdisciplinary Studies, 2 (7): 181188.

[15] O. A. Olorode (2016). Exploring education as an instrument for building a sustainable future Nigeria. Kumbotso Teacher Educator, 7 (1): 84-94.

[16] P. O. M. Nnabuo and J. D. Asodike (2012). Exploring education as a tool for sustainable development in Nigeria. European Scientific Journal, 8 (10): 1-11.

[17] J. L. Yahaya (2017). Biology Education as a tool for Achieving Sustainable Development and Sustainability. Being a paper presented at 2nd National science education conference held at Saadatu Rimi College of Education, Kumbotso, Kano, on 31st October-3rd.

[18] S. Sharma (2012). Bioremediation: Features, strategies and applications. Asian Journal of Pharmacy and Life Sciences, 2 (2): 202-213.

[19] R. Singh, P. Singh and R. Sharma (2014). Microorganisms as a tool of Bioremediation Technology for Cleaning Environment: A Review. Proceeding of the International Academy of Ecology and Environmental Sciences, 4 (1): 1-6. 